\title{
Effect of silicon and algae extract foliar application on growth and early yield of globe artichoke plants.
}

\author{
Sayed, S.M.*;Abd El-Dayem,H.M.**;El-Desouky,S.A.**;Khedr,Z.M.**;Samy,M.M.* \\ *Potato and Vegetative Propagated Vegetables Department, Hort. Res. Inst., A.R.C \\ **Plant Botany Department, Faculty of Agriculture, Benha University, Egypt \\ Corresponding author: hosny abdeldayem@yahoo.com
}

\begin{abstract}
Field experiments were carried out in Vegetables Research Farm of Kaha, Kalyoubia, Horticulture Research Institute, A.R.C., Egypt to investigate the effect of sprayingwith silicon (1000 and $2000 \mathrm{ppm} \mathrm{SiO2)}$ or algae extract $(2 \mathrm{ml} / \mathrm{L}$ and $4 \mathrm{ml} / \mathrm{L})$ sprayed twice at 45 and 60 days after planting on the growth, early yield, total yield and chemical components on globe artichoke plants of French cultivar (Hyrious) which were grown under drip irrigation during the two successive seasons of 2015/2016 and 2016/2017. The obtained results showed that globe artichoke plants were sprayed with silicon $(2000 \mathrm{ppm} \mathrm{SiO} 2)$ or algae extract $(4 \mathrm{ml} / \mathrm{L})$ recorded the highest significant increase in all studied growth characters (i.e., plant height, numbers of leaves per plant, total leaves area per plant, fresh and dry weight of shoot). As well as significant increase in the yield parameters (i.e., head diameter, fresh head weight, head length, fresh and dry weight of receptacle) also, the same treatments recorded the highest values of early and total yield per feddan and significant increase chlorophyll a, b , total chlorophyll , in nitrogen, phosphorus and potassium concentrations as well as total sugar and total amino acid concentrations followed by plants sprayed with silicon $(1000 \mathrm{ppm} \mathrm{SiO} 2)$ or algae extract $(2 \mathrm{ml} / \mathrm{L})$ in the two successive seasons when compared with untreated plants.

Conclusively, from that obtained data in this study, it can be recommend the use silicon (2000 ppm $\mathrm{SiO} 2)$ or algae extract (4ml/L)as foliar spray on globe artichoke plants for improve their growth, early and total yield.
\end{abstract}

Key words: Globe artichoke, Silicon (SiO2), Algae extract, and Stimulation growth.

\section{Introduction}

Globe artichoke (Cynarascolymus L.) belongs to composite family (Asteraceae). It is one of the important vegetable crops grown in Egypt for local markets and exportation. The period from December to February is the best time for exportation to European countries, this represents a vital importance since production is low and prices are high. Silicon (Si) fertilizer is known as an ecologically compatible and environmental friendly technique to stimulate plant growth. Silicon was reported to reduce the hazard effects of various abiotic and biotic stresses including salt stress, metal toxicity, drought stress, radiation damage, various pests and diseases caused by both fungi and bacteria, nutrients imbalance, high temperature and freezing (Ma, 2004; Etesamy and Jeong 2018). Silicon has emerged as an important nutrient for a range of horticultural crops i.e., cucumber, strawberry and tomato ( Ma , 2004). Higher plants can be divided into $\mathrm{Si}$ accumulators and nonaccumulators according to their $\mathrm{Si}$ content and $\mathrm{Si} / \mathrm{Ca}$ ratio. Si accumulators show a characteristic distribution in the phylogenetic system. Three modes of Si uptake are recognized, i.e., active (rice), passive (cucumber), and exclusive (tomato). Si not only contributes cell wall elasticity during extension growth in the primarily cell walls Si interacts with cell constituents such as pectins and polyphenols, and these crosslink obviously increase cell wall elasticity during extension growth as well as increasing of silicon absorption also led to maintain erect leaves and importance of leaf angle to photosynthesis (Yoshida et al., 1969; Emadian and Newton, 1989). Foliar application of pea plants with silicon as well as sodium meta silicate significantly increased early yield, total fresh yield and seeds fresh weight per feddan (Gharib and Hanafy Ahmed 2005). Moreover, Seaweed extracts have been used as soil conditioners, fertilizers and as a foliar spray for many crops (Norrie and Keathley 2006). The value of seaweeds as well as algae extracts applications were due to the presence of trace elements ( N, P, Fe, Cu, Zn, Co, Mo, Mn, Ni) and metabolites. The extract also contains hormones (IAA and IBA), cytokinins, vitamins, enzymes and amino acids. These extracts enhance seed germination, growth, yield, improved quality and longer shelf life of fruits, uptake of nutrients by the plants and more resistance to biotic and abiotic stresses (fungal diseases, insect attack and frost) (Booth, 1969;Blunden, 1991). Therefore, the present work was conducted to through some light on optimal means that may induce earliness and improve yield of artichoke heads for consumption and exportation. The effect of Silicon (Sodium meta silicate) or algae extract on the earliness yield of French cultivar (Hyrious) of globe artichoke plant was studied.

\section{Material and Methods}

Field experiments were conducted during the two successive seasons of 2015/2016 and 2016/2017 in Vegetables Research Farm of KahaKalyoubia, Hort. Res. Inst., Egypt to study the effect of foliar applications with Silicon (Sodium meta silicate) or 
algae extract on globe artichoke plants under drip irrigation system.

The propagated parts of globe artichoke plants cv. Hyrious was prepared by dividing the old crown into pieces with at least two basal buds/ piece after detaching the old leaves and pruning the roots. Propagation parts were,then, planted in the field on 15 th of September in both seasons of the study. The recommended agricultural practices of globe artichoke including fertilization, irrigation and pests managements were done according to the Egyptian Ministry of Agriculture.
Field experimental area was divided into plots (21 $\mathrm{m} 2$ ). Each plot contained four rows each one was seven meter length and one meter width. Each row included 7 plants. The experiment included 5 treatments which two concentrations of Silicon (Sodium meta silicate) (1000 and $2000 \mathrm{ppm} \mathrm{SiO} 2$ ) and algae extract $(2 \mathrm{ml} / \mathrm{L}$ and $4 \mathrm{ml} / \mathrm{L})$, and Control (spraying plants with tap water).

The soil type of the experimental area was clay loamy. Chemical analysis and physical properties of soils determined according to methods reported by Jackson (1973) shown in Table 1.

Table 1. Physical and chemical analysis of soil.

\begin{tabular}{|c|c|c|c|c|c|c|c|c|}
\hline \multirow{2}{*}{ Season } & Clay & Silt & Sand & \multirow{2}{*}{ Texture class } & \multirow{2}{*}{$\begin{array}{l}\mathrm{pH} \\
\text { (1-2.5 suspension) }\end{array}$} & \multicolumn{3}{|c|}{ Chemical Available (ppm) } \\
\hline & $\%$ & & & & & $\mathrm{~N}$ & $\mathrm{P}$ & $\mathrm{K}$ \\
\hline 2016 & 61.0 & 21.4 & 17.6 & Clay loam & 7.4 & 87.9 & 26.2 & 85.2 \\
\hline 2017 & 60.4 & 22.2 & 17.4 & Clay loam & 7.6 & 64.2 & 28.2 & 77.0 \\
\hline
\end{tabular}

Foliar application treatments were as follow in both seasons, at 45 and 60 days after planting, foliar application with Silicon as Sodium meta silicate ( $\mathrm{Na} 2 \mathrm{SiO} 35 \mathrm{H} 2 \mathrm{O})$ was used at the rates of 1000 and 2000 ppm SiO2. Foliar application with algae extract (The blue alga Spirulina platensis was produced at Algal Biotechnology Unit, National research Centre) was used at the rates of $(2 \mathrm{ml} / \mathrm{L}$ and $4 \mathrm{ml} / \mathrm{L})$.

In both successive seasons, five plants were randomly taken after 90 days from planting to determine the following growth characters: plant height $(\mathrm{cm})$, number of leaves per plant, fresh and dry weight $(\mathrm{g})$ of shoot as well as total leaves area per plant (m2).

Determination of $\mathrm{N}, \mathrm{P}$ and $\mathrm{K}$ were carried out on dry material of leaves. Nitrogen concentration was determined by Nesslar method according to AOAC (1960). Phosphorus was estimated calorimetrically using the reduced molybdophosphoric blue color method according to Jackson (1973). Potassium was determined using the flame photometer (CORNING, M 410).

Ethanol extract of leaves used for the determination of total sugar and total free amino acids. Total sugars were determined by using the phenol sulphoric acid reagent (Dubois et al., 1956). Total free amino acids were determined by using ninhydrin reagent (Moore and Stein, 1954). Fresh leaves were extracted with dimethyl and placed overnight at cool temperature $\left(5^{\circ} \mathrm{C}\right)$. were determined Chlorophyll (a), (b) and total chlorophyll according to Nornai (1982).

At harvest, yield was determined as heads weight (ton/fed.) and (number of heads/fed) including early yield and total yield (early, middle and late yield) and head characters were estimated of early yield as following: head diameter $(\mathrm{cm})$, fresh head weight $(\mathrm{g})$, head length $(\mathrm{cm})$, fresh weight of edible part (receptacle) $(\mathrm{g})$, and dry matter of the edible part (receptacle) (g).

The experimental design was complete randomize plots. Data were analysis using analysis of variance (ANOVA) and the means were compared using the least significant difference test (LSD) at $5 \%$ level (Snedecor and Cochran, 1980).

\section{Results and Discussion}

\section{A- Vegetative growth characters:}

Regarding the effect of spray silicon or algae extract on globe artichoke plants, the data presented in Table (2) revele that, the all of foliar application treatments caused a significant increase in the all growth characters at 90 days after planting i.e., shoot height, leaves numbers per plant, leaf area, shoot fresh weight and shoot dry weight in the two successive seasons. While, the highest level of silicon (2000 ppm $\mathrm{SiO} 2)$ had the superiority effect in the all growth characters followed by algae extract $(4 \mathrm{ml} / \mathrm{L})$ when compared with control plants.

Presented results are in harmony with those reported by Garibe and Hanafy Ahmed (2005) on Pea those stated that, silicon (sodium meta silicate) foliar application caused a significant in plant height, number of leaves / plant and the total leaves area. Also, Morgan (2007) on wheat reported that the mean values all of the studied growth characters were increased at 90 days by using both the lowest $(250$ ppm SiO2) and highest (1000ppm SiO2) levels of silicon (sodium meta silicate).Moreover, (Kamenidou and Cavins 2008) studied that thick, straight stems, increased flower and stem diameters, and increased height were observed in some of the Silicon supplements treatments, upgrading sunflower quality compared with untreated controls. Also these results are in agreement with those reported by Miyake and Takahashi (1983) and Lee et al., (1991) on cucumber they reported that, Si application promoted the growth of cucumber and marked increased in growth. In addition, Morgan (1999) on lettuce and Lee and Cheon (2000) and Ma et al., (2004) on cucumber suggested that supplying Si was increased total fresh weight, leaf fresh weight, total cholorophyll and enhanced the rigidity mature leaves. Furthermore, Guo et al., (2005) on rice reported that Si lead to 
increased shoot dry weight as well as RemeroAranda et al., (2006) found that, Si improves the water storage

Table 2. Growth characters of globe artichoke plant sprayed by different levels of silicon or algae extract at 90 days after planting during seasons of 2015/2016 and 2016/2017.

\begin{tabular}{clllll}
\hline $\begin{array}{c}\text { characters } \\
\text { treatments }\end{array}$ & $\begin{array}{l}\text { Shoot height } \\
(\mathrm{cm})\end{array}$ & $\begin{array}{l}\text { Leaf } \\
\text { area/plant } \\
(\mathrm{m} 2)\end{array}$ & $\begin{array}{l}\text { Leaves number } \\
\text { per plant }\end{array}$ & $\begin{array}{l}\text { Shoot fresh } \\
\text { weight }(\mathrm{g})\end{array}$ & $\begin{array}{l}\text { Shoot weight }(\mathrm{g}) \\
\text { weing }\end{array}$ \\
\hline
\end{tabular}

\begin{tabular}{llllll}
\hline & \multicolumn{5}{c}{ 2015-2016 Season } \\
\hline Control & 96.60 & 6.677 & 42.67 & 3116.3 & 188.54 \\
\hline $\mathrm{Si}(1000 \mathrm{ppm} \mathrm{SiO} 2)$ & 106.73 & 7.140 & 49.33 & 3359.4 & 240.82 \\
\hline $\mathrm{Si}(2000 \mathrm{ppm} \mathrm{SiO} 2)$ & 109.52 & 8.433 & 52.33 & 3854.3 & 249.90 \\
\hline Algae extract (2m1/L) & 104.50 & 6.917 & 43.40 & 3344.0 & 233.47 \\
\hline Algae extract (4m1/L) & 106.73 & 7.917 & 50.63 & 3378.3 & 240.90 \\
\hline $\begin{array}{l}\text { L.S.D. 5\% significant } \\
\text { level }\end{array}$ & 3.97 & 0.764 & 4.40 & 479.48 & 12.25 \\
\hline & & $\mathbf{2 0 1 6 - 2 0 1 7}$ Season & & 3232.7 & 186.73 \\
\hline Control & 95.83 & 7.34 & 42.33 & 3470.3 & 240.66 \\
\hline Si (1000 ppm SiO2) & 109.17 & 8.63 & 46.33 & 3636.0 & 251.90 \\
\hline Si (2000 ppm SiO2) & 110.83 & 9.07 & 46.67 & 3331.3 & 233.92 \\
\hline Algae extract (2m1/L) & 108.00 & 8.30 & 45.35 & 3486.6 & 241.90 \\
\hline Algae extract (4m1/L) & 110.33 & 8.85 & 46.33 & 109.11 & 5.87 \\
\hline $\begin{array}{l}\text { L.S.D. 5\% significant } \\
\text { level }\end{array}$ & 3.72 & 0.48 & 1.45 & & \\
\hline
\end{tabular}

Merwad et al., (2018) reported that, under water deficit stress, foliar application of proline, $\mathrm{Si}$ or methionine seemed to overcome the harmful effects of water deficit stress. Silicon stimulates growth and yield by decreasing mutual shading by improving leaf erecters, decreasing susceptibility to loading, $\mathrm{Si}$ also provides the mechanical strength to different organs and particularly to the stem which, in turn, prevents lodging (Mitsui and Takatoh, 1963). Reduces water loss by cuticular transpiration by decreasing the nonstomatal (cuticular) component of transpiration (Marschner, 1995; savant et al., 1997). On the other view, Lu and Cao (2001) postulated that, no effects of supplementary silicate on shoot growth of melon plants. However, the fresh weight of root and the root: shoot ratio were significant increased and cause obvious reduction in transpiration.

Liquid seaweed extract has been reported as a beneficial treatment for the growth of plants (Metting et al., 1990). Presented results are in harmony with those reported by Shahira et al., (2015) indicated that foliar application of algae extract to fenugreek plants significantly increased plant height, number of leaves, number of branches, fresh and dry weights of plant at vegetative growth stage and flowering stage. Also, Abdl-Aziz et al., (2011) who reported that the application of seaweed had a significant stimulatory effect on growth parameters of Amaranthus tricolor plants. The stimulatory effects of algae extract on all previous groth characters (shoot height, leaves numbers per plant, leaf area, shoot fresh weight and shoot dry weight) may be due to its content the plant growth promoting substances such as (cytokines, auxins, gibberellins, amino acids and vitamins) which reflected on enhancing of growth characters by affecting on enhance cells division and differentiation activity, activities many enzymes, increasing leaves growth and photosynthesis capacity.

Seaweed extracts have been reported to root and shoot development of Kentucky bluegrass (Poapratensis L.) (Goatley and Schmidt 1990). Also, Ahmed and Shalaby (2012) studied the effect of different seaweed extract and compost on cucumber they indicate that the all vegetative characters in cucumber plants was significantly affected by applying different treatments. Applying the T7 (Green alga, E. intestinelis + compost) and T4 (Green alga, E. intestinelis) treatments produced the long plants having the highest number of leaves, highest fresh, dry weight and largest leaf area. In addition Thirumaran et al. (2009) on okra plant (Abelmoschusesculentus) reported that seed germination, shoot length, root length, number of lateral roots, number of leaves, number of vegetables, length of vegetables, weight of vegetables, chlorophyll ' $a$ ', chlorophyll ' $b$ ', total chlorophyll were found maximum at $20 \%$ seaweed liquid (Rosenvigeaintricatawith) with or without chemical fertilizer. Mohammed (2013) on pepper found that spraying Seamino or Ascorbic acid led to positive significant difference in plant height, leaves chlorophyll content, as compared to untreated plants. Moreover, in a study by (Rayorath et al., 2009) extract of A. nodosum have been shown to affect the root growth of Arabidopsis at very low concentrations (0.1 g L-1), whereas plant height and number of leaves were affected at concentrations of

$1 \mathrm{gL}^{-1}$. Plants treated with extracts showed growth enhancement effects for example, plants treated with A. nodosum extract were at a more advanced 
developmental stage and the effect was concentration dependent.

\section{B-Chemical composision:}

Regarding the effect of treatments, silicon or algae extract on $\mathrm{N}, \mathrm{P}$ and $\mathrm{K}$ concentrations in leaves, data presented in Table (5) indicate that, silicon or algae foliar applications led to significant increase of the both seasons especially silicon (2000 ppm SiO2) or algae extract $(4 \mathrm{ml} / \mathrm{L})$ when compared with the control plants. While algae extract $(4 \mathrm{ml} / \mathrm{L})$ had superiority for significant increase in total amino acids followed by the others treatments (Table 5). Moreover, concerning total sugar concentration in leaves data in Table (5) revealed that silicon (1000 ppm $\mathrm{SiO} 2$ and $2000 \mathrm{ppm}$ $\mathrm{SiO} 2)$ or algae extract $(2 \mathrm{ml} / \mathrm{L}$ and $4 \mathrm{ml} / \mathrm{L})$ recorded significant increase when compared with non-treated plants during the two seasons. In this respect, it is clear from the results in Table (5) that high amount of total sugar and total free amino acids concentrations in leaves of treated plants with silicon or algae extract might effect of early flowering as well as early and total yield. This developing buds and heads had a competition for nutrients (N, P and $\mathrm{K}$ ) and carbohydrate suppling from the leaves. Thus, the development of buds, heads during the sample at 90 days from planting might be a result of early and total yields. It could be a cause of the poll size of nutrients $(\mathrm{N}, \mathrm{P}$ and $\mathrm{K})$, total amino acids and total sugars in vegetative parts. These results were in agreement with Gharibe and Hanafy Ahmed (2005) on peas found that, spraying sodium meta silicate twice at, 40 and 60 days after sowing was caused a significant increase in $\mathrm{K}$ concentration of pea seeds and organic components (total sugars and total free amino acids) concentrations.

Table 5. Chlorophyll a, b and total chlorophyll concentration (mg/g F.W.), Total sugars (mg/g F.W), Total free amino acids (mg/g F.W), and mineral nutrients (\%) in leaves of globe artichoke plants sprayed with different levels of silicon and algae extract during seasons of 2015/2016 and 2016/2017.

\begin{tabular}{|c|c|c|c|c|c|c|c|c|}
\hline characters & $\begin{array}{l}\text { Chlorop } \\
\text { hyll } \\
\quad \text { (a) } \\
\text { (mg/g } \\
\text { F.W.) }\end{array}$ & $\begin{array}{l}\text { Chlorophyll } \\
\text { (b) } \\
\text { (mg/g F.W) }\end{array}$ & $\begin{array}{l}\text { Total } \\
\text { Chlorophyll } \\
\text { (mg/g F.W) }\end{array}$ & 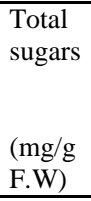 & $\begin{array}{l}\text { Total } \\
\text { free } \\
\text { amino } \\
\text { acids } \\
(\mathrm{mg} / \mathrm{g} \\
\text { F.W })\end{array}$ & $\begin{array}{c}\text { Nitrogen } \\
(\%)\end{array}$ & $\begin{array}{c}\text { Phosphorus } \\
(\%)\end{array}$ & $\begin{array}{c}\text { Potassium } \\
(\%)\end{array}$ \\
\hline \multicolumn{9}{|c|}{ 2015-2016 Season } \\
\hline Control & 1.82 & 1.17 & 3.17 & 8.32 & 32.30 & 2.26 & 0.22 & 4.55 \\
\hline $\mathrm{Si}(1000 \mathrm{ppm} \mathrm{SiO} 2)$ & 2.07 & 1.44 & 3.61 & 11.91 & 36.02 & 2.29 & 0.26 & 5.23 \\
\hline $\mathrm{Si}(2000 \mathrm{ppm} \mathrm{SiO} 2)$ & 2.11 & 1.48 & 3.68 & 13.95 & 39.13 & 2.31 & 0.27 & 5.98 \\
\hline $\begin{array}{ll}\text { Algae } & \text { extract } \\
(2 \mathrm{ml} / \mathrm{L}) & \\
\end{array}$ & 1.81 & 1.41 & 3.36 & 11.94 & 36.08 & 2.31 & 0.25 & 5.33 \\
\hline extract & 2.11 & 1.45 & 3.66 & 13.93 & 37.88 & 2.33 & 0.27 & 6.10 \\
\hline $\begin{array}{l}\text { L.S.D. } 5 \% \\
\text { significant level }\end{array}$ & 0.62 & 0.79 & 0.89 & 0.67 & 1.33 & 0.41 & 0.08 & 0.92 \\
\hline \multicolumn{9}{|c|}{ 2016-2017 Season } \\
\hline Control & 1.88 & 1.17 & 3.24 & 8.33 & 31.90 & 2.26 & 0.22 & 4.51 \\
\hline $\mathrm{Si}(1000 \mathrm{ppm} \mathrm{SiO} 2)$ & 2.10 & 1.44 & 3.66 & 12.01 & 36.85 & 2.30 & 0.27 & 5.61 \\
\hline $\mathrm{Si}(2000 \mathrm{ppm} \mathrm{SiO} 2)$ & 2.15 & 1.48 & 3.69 & 14.13 & 39.00 & 2.32 & 0.29 & 6.33 \\
\hline $\begin{array}{ll}\begin{array}{l}\text { Algae } \\
(2 \mathrm{ml} / \mathrm{L})\end{array} & \text { extract } \\
\end{array}$ & 2.09 & 1.44 & 3.44 & 12.01 & 37.30 & 2.33 & 0.26 & 5.65 \\
\hline $\begin{array}{l}\text { Algae } \\
(4 \mathrm{ml} / \mathrm{L})\end{array}$ & 2.14 & 1.46 & 3.67 & 14.13 & 39.50 & 2.35 & 0.29 & 6.42 \\
\hline $\begin{array}{l}\text { L.S.D. } 5 \% \\
\text { significant level }\end{array}$ & 0.81 & 0.80 & 0.89 & 0.69 & 1.40 & 0.43 & 0.09 & 1.01 \\
\hline
\end{tabular}

Also, Morgan, (2007) on wheat reported that, the effect of silicon in nutrient concentrations the concentrations of $\mathrm{N}, \mathrm{P}, \mathrm{K}$ and $\mathrm{Ca}$ increased with all level of silicon foliar application (250, 500 and 1000 ppm $\mathrm{SiO} 2$ ) sodiummeta silicate reached to significant, with some exceptions. In this respect Shahira et al.,(2015) indicate that treatment of fenugreek plants with algae extract markedly increased nitrogen, phosphorous and potassium contents, especially at $5 \mathrm{~g} / \mathrm{L}$. Moreover, Ahmed andShalaby (2012) reported that T4 (Green alga, E. intestinelis) treatments caused significant increase in $\mathrm{N}, \mathrm{P}$ and $\mathrm{K}$ concentrations on cucumber plants. In addation, Yoshida et al., (1969) and Yoshida and Cock
(1970) noted that, silicon application resulted in $10 \%$ increase in the photosynthesis on rice.

\section{C- Aarly Yield and its components.}

Concerning the effect of silicon or algae extract on the early yield and its components, data in Tables (3 and 4) show that, all foliar applications treatments caused a significant increase in early heads yield (number of heads/feddan and weight of heads tons/feddan), total yield (number of heads/feddan and weight of heads ton/feddan) and early yield components i.e., head diameter, head length, head fresh weight, receptacle fresh and dry weight of receptacle. The maximum values of early yield and its components were obtained with the highest level of silicon (2000 ppm SiO2) followed by the highest level 
of algae extract $(4 \mathrm{ml} / \mathrm{L})$ in the two successive seasons when compared with control plants. These results could be related to the increase in shoot dry weight and other growth characters (Table 2) which were resulted from the foliar application of silicon $(2000$ ppm SiO2) or $4 \mathrm{ml} / \mathrm{L}$ algae extract. Moreover, treated plants with silicon or algae extract had a significant increase in chlorophyll (a), (b) and total chlorophyll as show in Table (5) it could enhance photosynthesis and carbohydrates accumulation were led to early flowering as well as early and total yield.

The presented results are in accordance with finding of Puzrkov and Dorozhkina (1996) and Lu and Coa (2001) who demonstrated that, using silicon led to earlier flowering on melon plants. Furthermore, foliar application with silicon as well as sodium meta silicate significantly increased early yield, total fresh yield and seeds fresh weight per feddan also caused to significant decreased in number of days from sowing to anthesis of flowers as reported by Gharib and Hanafy Ahmed (2005) on pea plants. As Morgan (1999) on dwarf beans, who reported that, suppling silicon led to increased total yield by $25 \%$ and marketable yield by $30 \%$. In addition, Morgan (2007) on wheat indicated that, all measured yield components increased significantly by silicon, moreover, the result indicated that the lowest level of silicon (250 ppm SiO2) had the superiority effect followed by the highest level (1000 ppm SiO2), while, the middle level of silicon (500 ppm SiO2) had the superiority increasing straw weight. Also, Miyake and Takahshi, (1983) on cucumber indicated that, using silicon caused a significantly increase in yield. Moreover, they indicated that silicon supply not only reduced fruit yield drastically, malformation of newly developed leaves, wilting and premature senescence improved pollen viability, and in severe cases failure of fruit set. Furthermore, Merwad et al. (2018) indicated that, under water deficit stress, foliar applications of proline, $\mathrm{Si}$ or methionine overcome the harmful effects of water deficit stress.

In many crops as well as globe artichoke yield is associated with the number of flowers at maturity. Seaweed concentrates triggers early flowering and fruit set in a number of crop plants (Abetz and Young 1983).

Table 3.Early Yield components of globe artichoke plants sprayed by different levels of silicon or algae extract during seasons of 2015/2016 and 2016/2017.

\begin{tabular}{|c|c|c|c|c|c|}
\hline $\begin{array}{l}\text { Components } \\
\text { treatments }\end{array}$ & $\begin{array}{l}\text { Length of } \\
\text { head }(\mathrm{cm})\end{array}$ & $\begin{array}{l}\text { Diameter of } \\
\text { head }(\mathrm{cm})\end{array}$ & $\begin{array}{c}\text { Fresh weight } \\
\text { of head }(\mathrm{g})\end{array}$ & $\begin{array}{l}\text { Fresh weight of } \\
\text { receptacle }(g)\end{array}$ & $\begin{array}{l}\text { Dry weight of } \\
\text { receptacle }(g)\end{array}$ \\
\hline \multicolumn{6}{|c|}{ 2015-2016 Season } \\
\hline control & 9.97 & 7.97 & 289.67 & 72.33 & 13.98 \\
\hline $\mathrm{Si}$ (1000ppm SiO2) & 11.30 & 9.30 & 374.17 & 95.50 & 17.28 \\
\hline $\mathrm{Si}$ (2000ppm SiO2) & 12.40 & 10.30 & 505.50 & 141.07 & 21.96 \\
\hline Algae extract $(2 \mathrm{ml} / \mathrm{L})$ & 10.47 & 8.07 & 323.86 & 79.73 & 16.13 \\
\hline Algae extract $(4 \mathrm{ml} / \mathrm{L})$ & 11.40 & 9.35 & 445.83 & 121.33 & 18.03 \\
\hline $\begin{array}{c}\text { L.S.D. 5\% significant } \\
\text { level }\end{array}$ & 1.36 & 1.02 & 72.31 & 25.33 & 3.54 \\
\hline \multicolumn{6}{|c|}{ 2016-2017 Season } \\
\hline control & 10.57 & 8.80 & 346.50 & 188.00 & 17.00 \\
\hline $\mathrm{Si}$ (1000ppm SiO2) & 13.83 & 11.50 & 490.50 & 212.67 & 30.28 \\
\hline $\mathrm{Si}$ (2000ppm SiO2) & 14.80 & 12.13 & 553.83 & 216.33 & 32.04 \\
\hline Algae extract $(2 \mathrm{ml} / \mathrm{L})$ & 13.50 & 11.47 & 490.50 & 204.00 & 26.99 \\
\hline Algae extract $(4 \mathrm{ml} / \mathrm{L})$ & 13.63 & 11.57 & 490.83 & 214.00 & 31.39 \\
\hline $\begin{array}{c}\text { L.S.D. 5\% significant } \\
\text { level }\end{array}$ & 0.74 & 0.84 & 56.52 & 14.23 & 2.31 \\
\hline
\end{tabular}

The positive effect of algae extract on early yield and its components may be attributed to increasing the leaf area and leaves number per plant (Table 3 ) as well as increasing the amount of chlorophyll, total amino acids, total sugar and mineral nutrients (Table 5) resulting stimulation in the supply of photosynthesis due to increasing the rate of net amount of photoassimilate transport from sites of synthesis in leaf tissue source to sites of the sink of reproductive organs ( heads), which reflected upon and its components. In this respect our results are in accordance with Thirumaran et al. (2009) seaweed liquid fertilizer produced higher growth, yield and chlorophyll. In many crops as well as globe artichoke yield is associated with the number of flowers at maturity. Seaweed concentrates triggers early flowering and fruit set in a number of crop plants (Abetz and Young 1983). As the onset and development of flowering and the number of flowers produced are linked to the developmental stage of plants, seaweed extracts probably encourage flowering by initiating robust plant growth, yield increases in seaweed-treated plants are thought to be associated with the hormonal substances present in the extracts, especially cytokinins (Featonby-Smith and van Staden 1983). Cytokinins in vegetative plant 
organs are associated with nutrient partitioning, whereas in reproductive organs, high levels of cytokinins may be linked with nutrient mobilization.
Fruit ripening generally causes an increase in transport of nutrient resources within the developing plant (Adams-Phillips, et al., 2004).

Table 4.Early and total Yield of globe artichoke plants sprayed by different levels of silicon or algae extract during seasons of 2015/2016 and 2016/2017.

\begin{tabular}{lllll}
\hline \multirow{2}{*}{ Yield } & \multicolumn{2}{c}{ Early yield } & \multicolumn{2}{c}{ Total yield } \\
\cline { 2 - 5 } treatments & Number/fed. & Ton. /fed. & Number/fed. & Ton. /fed. \\
\hline & \multicolumn{3}{c}{ 2015-2016 Season } \\
\hline Control & 3541 & 1.23 & 35389 & 12.83 \\
\hline $\mathrm{Si}(1000 \mathrm{ppm} \mathrm{SiO2)}$ & 24916 & 5.43 & 45069 & 18.13 \\
\hline $\mathrm{Si}(2000 \mathrm{ppm} \mathrm{SiO2)}$ & 25324 & 6.90 & 46489 & 19.85 \\
\hline Algae extract (2m1/L) & 24900 & 4.22 & 44910 & 17.96 \\
\hline Algae extract (4m1/L) & 25098 & 5.72 & 45981 & 19.51 \\
\hline L.S.D. 5\% significant level & 276.62 & 0.82 & 1421.4 & 0.99 \\
\hline & & $2016-2017$ Season & & 14.57 \\
\hline Control & 3641 & 1.41 & 37351 & 21.00 \\
\hline Si (1000ppm SiO2) & 25322 & 5.72 & 46624 & 21.47 \\
\hline Si (2000ppm SiO2) & 25921 & 6.24 & 47287 & 18.82 \\
\hline Algae extract (2m1/L) & 25308 & 4.33 & 45291 & 19.51 \\
\hline Algae extract (4m1/L) & 25713 & 5.21 & 46798 & 0.80 \\
\hline L.S.D. 5\% significant level & 196.21 & 0.96 & 334.33 & \\
\hline
\end{tabular}

Seaweed extract increased fruit yield when sprayed on tomato plants during the vegetative stage, producing large sized fruits $30 \%$ increase in fresh fruit weight over the control) with superior quality (Crouch and van Staden 1992). Norrie and Keathley (2006) have reported that A. nodosum extracts showed positive effects on the yield of "Thompson seed-less' grape (Vitisvinifera L.) consistently over a 3-year period. They observed that the A. nodosum treated plants always outperformed the controls, and resulted in improved fruit size (13\% increase), weight (39\% increase), and yields $(60.4 \%$ increase over the control). Moreover, Mohammed (2013) stated that spraying pepper with Seamino led to positive significant difference in leaves total yield as well as fruit diameter, fruit length, fruit dry weight, TSS \%, fruit weight, yield per plant and total yield.

\section{References}

A.O.A.C. (1960).Official Methods of Analysis (9th Ed).Association of Official Analytical Chemists.Washington D.C.,USA.

Abdel-Aziz, N.G.; Mahgoub, M.H. and Siam, H.S. (2011). Growth, flowering and chemical constituentsperformence of Amaranthus tricolor plants as influenced by

derived fromAscophyllumnodosum on lettuce and cauliflower crops. Bot. Mar. 26: 487-492.

Adams-Phillips, L.; Barry, C. and Giovannoni, J. (2004). Signal transduction systems regulating fruit ripening. Trends Plant Sci. 9: 331-339.

Ahmed, Y.M. and Shalaby, E.A. (2012). Effect of different seaweed extracts and compost on vegetative growth, yield and fruit quality of cucumber. J. Horti. Scie. \& Ornamental Plants 4 (3): 235-240.

Blunden, G. (1991). Agricultural uses of seaweeds and seaweed extracts. In: Guiry, M.D, Blunden, G. (eds) Seaweed resources in Europe: uses and potential. Wiley, Chicester, pp 65-81.

Booth, E. ( 1969). The manufacture and properties of liquid seaweed extracts. Proc. Int. Seaweed Symp. 6: 655-662.

Chapman, H.D. and Pratt, P.F.(1978). Methods of analysis for soils, plants and waters. Division of Agricultural Sciences, University of California, Berkeley, USA.

Crouch, I.J. and van Staden, J. (1992). Effect of seaweed concentrate on the establishment and yield of greenhouse tomato plants. J. Appl. Phycol. 4: 291-296.

Dubois, M.; Smith, F.; Gilles, K.A; Hamilton, J.K. and Rebers, P.A. (1956). Colorimetric method for determination of sugars and related substances. Annal. Chem., 28(3):350-356.

Emadian, S.F. and Newton, R.J. (1989). Growth enhancement of Loblolly pine (Pius taeda L) seedlings by silicon. J. Plant Physiol. 134: 98-103.

Etesamy, H. and Jeong, B.R. (2018). Silicon (Si): Review and future prospects on the action mechanisms in alleviating biotic and abiotic stresses in plants. Ecotoxicology and Enviro. Safety.147: 881-896.

Featonby-Smith, B.C. and van Staden, J. (1983). The effect of seaweed concentrate on the growth of tomato plants in nematode-infested. soil. Sci. Hortic. 20:137-146. 
Gharib, A.A and Hanafy Ahmed, A.H. (2005). Response of pea plants (Pisumsativum, L.) to foliar application of putrescine, glucose, folia feed D® and silicon . J. Agric. Sci. Mansorra Univ. 30(12): 7563-7579.

Goatley, J.M.Jr. and Schmidt, R.E. (1990). Seedling Kentucky bluegrass growth responses to chelated iron and biostimulator materials. Agron. J. 82 (5): 901-905.

Guo, W.; Hou, Y.L.; Wang, S.G. and Zhu, Y.G. (2005). Effect of silicate on the growth and arsenate uptake by rice (Oryza sativa L.) seedlings in solution culture. Plant Soil 272 (1-2): 173-181.

Jackson, M.L. (1973). Soil Chemical Analysis. Printice-Hall of India. Privat Limited, New Delhi.

Kamenidou, S. and Cavins, T.J. (2008). Silicon supplements affect horticultural Traits of greenhouse-produced ornamental sunflowers. Hort. science 43(1): 236-239.

Lee, C.H. and Cheon, S.G. (2000). Effect of silicate fertilizer on paddy garlic (Allium sativum L.). Research Reports of the Rural Development Administration, Soil and Fertilizer. 33(2): 61-66.

Lee, Y.B; Kweon, J.S.; Bae, G.Y. and Shin, K.C. (1991). Effects of silicon on mineral nutrient uptake, growth and manganese toxicity of cucumber plants in hydroponics. J. the Korean Society Hort. Sci., 32(2): 146-156.

Lu, G. and Cao, J. (2001) Effect of silicon on earliness and photosynthetic characteristics of melon. Acta Hort. Sci. 28(5):421-424.

Ma, J.F. (2004). Role of silicon in enhancing the resistance of plants to biotic and a biotic stress. Soil Sci. Plant Nutr. 50(1): 11-18.

Marschner, H. (1995). Mineral Nutrition of Higher Plants.( 2nd Ed.), Academic press, Harcout Brace Company .Publishers London, San Diego, new York, Boston, Sydney, Tokyo, Toronto.,pp.786.

Merwad, A.M.A.;Desoky, E.M. and Rady, M.M.(2018). Response of water deficit stressed Vignaunguiculata performances to silicon, proline or methionine foliar application. ScientiaHorti., 228: 132-144.

Metting, W.; Zimmerman, J.; Crouch, I.J. and Van Staden, J. (1990). Agronomic uses of seaweed and micro-algae. p. 269-307. In: Akatsuka I (ed). Introduction to Applied Phycology. SPB Academic Publishers, Netherland.

Mitsui, S. and Takatoh, H. (1963). Nutritional study of silicon in graminaceous crops. Part.1. Soil Sci. Plant Nutr. 9: 49-53.

Miyake, Y. and Takahashi, E. (1983). Effect of silicon on the growth of solution cultured cucumber plant. Soil Sci. Plant Nutr. 29(1): 71-83.

Mohammed, G. H. (2013). Effect of Seamino and ascorbic acid on growth, yield and fruits quality of Pepper (Capsicum Annum L). Int. J. Pure. Appl. Sci. Technol. 17 (2): 9-16.

Moore, S. and Stein, W.H. (1954). Amodifiedninhydrin reagent for the photometric determination of amino acids and related compounds. J. Biol.Chem., 211:907-913.

Morgan, L. (1999). Adventures with silica. Commercial- Grower, 54(6): 22-29.

Morgan, Sh.H. (2007). Some physiological studies on wheat plants growing under salinity stress conditions. MSc. Thesis, Fac. Agric., Cairo Univ., Egypt.

Nornai, R. (1982). Formula for determination of chlorophyllus pigments extracted with N.N. dimethyl formamide. Plant Physiol., 69: 13761381.

Norrie, J.andKeathley, J.P. (2006). Benefits of Ascophyllumnodosum marine-plant extract applications to 'Thompson seedless' grape production. (Proceedings of the Xth International Symposium on Plant Bioregulators in Fruit Production, 2005). Acta. Hortic.727: 243-247.

Puzyrkov, P.E. and Dorozhkina, L.A. (1996). Application of tetraetoxisilant for increasing potato yield and for ecological safety of pesticides. IzvestiyaTimiryazevskoiSelskohozyaistvennoiAkademii., 2: 135-144.

Rayoath, P.; Benkel, B. Hodges, D.M.; Allan-Wojtas, P.; Mackinnon, S.; Critchley, A.T. and Prithiviraj, B. ( 2009). Lipophilic components of the brown seaweed, Ascophyllumnodosum, enhance freezing tolerance in Arabidopsis thaliana. Planta 230: 135147.

RemeroAranda, M.R.; Jurado, O. and Cuartero, J. (2006). Silicon alleviates the deleterious salt effect on tomato plant growth by improving plant water status. J. Plant physiol., 163 (8): 847-855.

Savant, N.K.; Datnoff, L.E. and Snyder, G.H. (1997).Depletion of plant- available silicon in soils: a possible cause of declining rice yields. Communications Soil Sci. plant Analysis, 28(13/14): 1245-1252.

Shahira, A. T.; Iman, M.T.; Abo El - Khair, B. E. and Laila, K. B. (2015). Iflunce of foliar application of algae extract and amino acids mixture on fenugreek plants in sandy and clay soil. Nusantara Bioscience. 7 (1): 33-37.

Snedecor, G.W. and Cochran, W.G. (1980). Statistical Methods. 7th ed. Iowa State University Press, Ames.

Thirumaran, G.; Arumugam, M.; Arumugam, R.; and Anantharaman, P. (2009). Effect of seaweed liquid fertilizer on growth and pigment concentration of abelmoschusesculentus (1) medikus. AmericanEurasian J. Agronomy 2 (2): 57-66.

Yoshida, S. and Cock, J. (1970). An assessment of the effects of silicate application on rice by astimulation method. Soil Sci. plant Nutr., 16:212214.

Yoshida, S.; Navasero, S.A and Ramirez, E.A. (1969).Effect of silica and nitrogen supply on some leaf characters of the rice plant. Plant Soil, $31: 48-56$ 


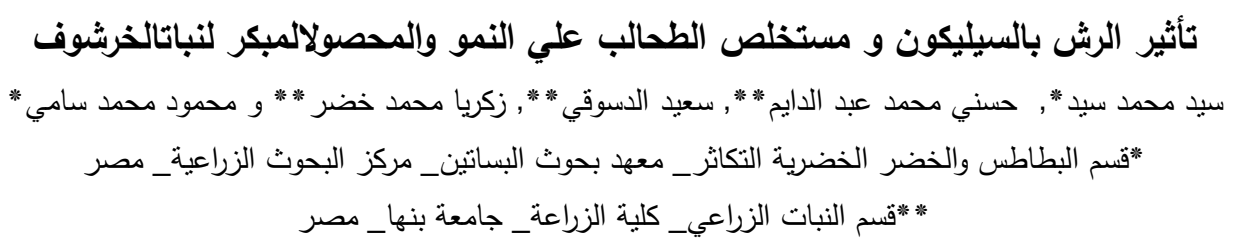

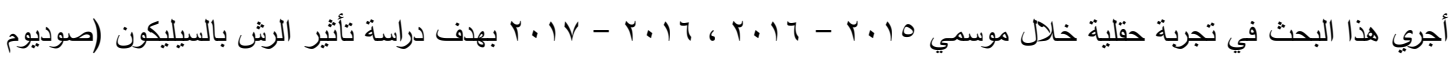

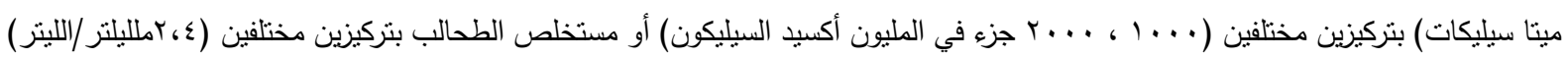

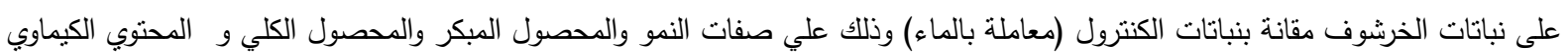
لنبات الخرشوف حيث تم الرش في عمري 0؛ و ـ ب يوم من الزراعة للصنف الفرنساوي (هيروس) النامي تحت نظام الري بالتنقيط.

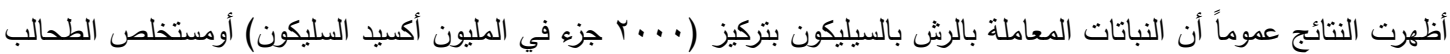
بتركيز (ع ملليلتر/الليتز) أعطت افضل النتائج من حيث الصفات الخضرية وصفات المحصول و قد سجلت أعلي نتائج معنويه في محتوي الاوراق

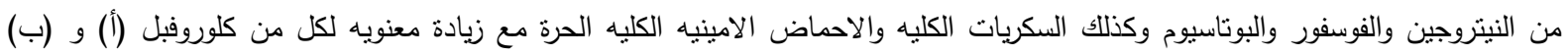

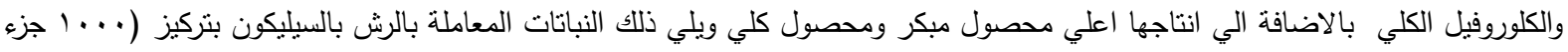

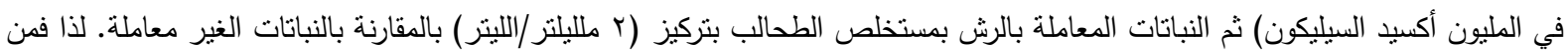

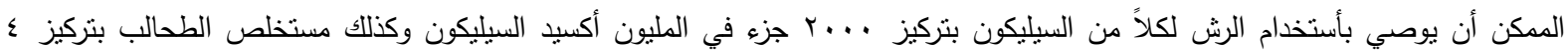
ملليلتر/الليتز للصنف الفرنساوي لنبات الخرشوف للحصول علي اعلي محصول مبكر صالح للنصدير للدول الأوروبية في اوقات الندرة. 